\title{
Eggshell Valorization: Membrane Removal, Calcium Oxide Synthesis, and Biochemical Compound Recovery towards Cleaner Productions
}

\author{
Samuel Aina ${ }^{1(\mathbb{D})}$, Barend Du Plessis ${ }^{1(\mathbb{D})}$, Vuyo Mjimba ${ }^{2(\mathbb{D})}$, Hendrik Brink ${ }^{1, *(\mathbb{D})}$ \\ 1 Department of Chemical Engineering, University of Pretoria, South Africa; ainasam000@gmail.com (S.A.), \\ barend.duplessis@up.ac.za (B.D.P.),deon.brink@up.ac.za (H.B.); \\ 2 Human Sciences Research Council, Pretoria, South Africa; vmjimba@hsrc.ac.za (V.M.); \\ * Correspondence: deon.brink@up.ac.za (H.B.);
}

Scopus Author ID 54404695600

Received: 24.08.2021; Revised: 27.09.2021 Accepted: 2.10.2021; Published: 24.10.2021

\begin{abstract}
As climate change continues to rank high among issues of global concern, industries such as agriculture and construction continue to unearth possible ways to curb carbon dioxide generation and encourage the use or reuse of a variety of by-products and waste materials, fostering the implementation of cleaner technologies. Eggshells form a notable component of this waste, making up more than 7.6 million metric tonnes annually. Research works involving the calcination of eggshells have often been done by burning both shell and its constituent proteins and membrane to produce calcium oxide, $\mathrm{CaO}$. This novel research investigated a cleaner means of $\mathrm{CaO}$ synthesis by recovering the shell membrane and some valuable chemical compounds from eggshells before calcination. Atomic absorption (AA), thermogravimetric analysis (TGA), scanning electron microscope (SEM), X-ray fluorescence analysis (XRF), X-ray diffraction (XRD), Ultra-performance-liquid chromatography quadrupole-time-of-flight mass spectrometry (UPLC-Q-TOF-MS), and RGB color analysis were all employed. Acetic and Nitric acid was used to weaken the shell-membrane bond, thereby aiding membrane separation. Shell membrane was easily separated after 17 minutes of soaking time. Calcium oxide, $\mathrm{CaO}$ was synthesized from separated shells after calcination for 3 hours at $900{ }^{\circ} \mathrm{C} .99 \% \mathrm{CaO}$ with an RGB value of 253 was produced. Collagen, as well as other chemical compounds, were recovered. Eggshell was successfully valorized for $\mathrm{CaO}$ production. The shell membrane, collagen, and other recovered compounds, which would have been burnt off and left as an impurity in the $\mathrm{CaO}$, can now the put to more profitable use.
\end{abstract}

Keywords: eggshells; Eircular economy; calcium oxide; waste valorisation; protein recovery; cleaner technology.

(C) 2021 by the authors. This article is an open-access article distributed under the terms and conditions of the Creative Commons Attribution (CC BY) license (https://creativecommons.org/licenses/by/4.0/).

\section{Introduction}

Global discourse in the twenty-first century is more than ever before aimed at adapting to and mitigating the effects of climate change with the improvement of human economic and social wellbeing at its core. This is because the effects of climate change impact almost all human activities and thus demand urgent and decisive action to address the adverse impacts simultaneously with the exploitation of any arising opportunities to advance human wellbeing [1]. The focus of managing climate change has been and remains two-pronged: learning to live with the adverse impacts of this phenomenon - the essence of adaptation on the one hand, and retarding or halting the increase of anthropogenic atmospheric greenhouse gases (GHGs) - the essence of mitigation on the other hand [2-4]. A major source of anthropogenic GHGs (also 
called carbon emissions) is the burning of fossil fuels for direct and indirect energy supply in commercial and social activities. Other sources include farming and waste management practices that rely on the traditional disposal of solid waste in dump areas. In these dumps, the waste decomposes, releasing methane - an extremely potent GHG. Contemporary approaches to managing waste and (tacitly) climate change encourage recycling, alternative uses of some waste materials, and ultimately advocating a zero-waste community (circular economy) [5-8].

The global awareness of the need to reduce carbon emissions has encouraged investigations on the use of alternative cementitious materials for concrete production [9]. This focus arises from the realization that the production of Portland cement clinker emits up to 1.5 billion tons of carbon (often denoted as carbon dioxide $-\mathrm{CO}_{2}$ ) annually. This accounts for about $5 \%$ of the total manufactured $\mathrm{CO}_{2}$ emission [10]. Simultaneously, the last few decades have witnessed tremendous waste generation due to increased industrialization and urbanization [11-13]. According to Kaza et al. [14], global waste generation was estimated at 2.01 billion tonnes in 2016, with a projection of 3.40 billion tonnes by 2050. In South Africa, reports show that 42 million tons of general waste were generated in 2017 [15]. Globally, 62 million tonnes of eggs were produced from domesticated chickens (Gallus gallus domesticus) in 2008 [16]. Over ten years, this statistic grew to 76.7 million metric tonnes in 2018 [17]. In this mix, the South African poultry industry produced 452,000 tonnes of eggs in 2018 [18]. With shells comprising about $10.2 \%$ of the whole egg and a constant increase in production, disposal of the waste shells will always be of huge concern.

The traditional approaches to the management of waste are disposed of in dumpsite and incineration. Both approaches contribute to GHG emissions. Modern approaches to managing waste advocates for the continual use of resources in the bid to eliminate waste and inhibit climate change. One such approach, called the Circular economy, elevates the principles of reuse, sharing, repair, renovation, remanufacturing, and recycling to create a closed system, curtailing the use of virgin inputs and the creation of waste pollution and emission [19,20]. The tenet of the approach is that all "waste" should become "food" for another process [5,7].

Calcareous, porous, and bioceramic in nature, eggs are the reproductive means of all birds and most reptiles. Oval in shape after years of adaptive evolution, the chicken egg is just strong enough to fight physical and pathogenic attacks from the environment and also not too hard to allow for the exchange of gas and water needed for the development of a growing embryo inside the shell [21,22]

An eggshell is made up of a calcified shell and a double layer of shell membrane. It is one of the best and most abundant sources of naturally occurring calcium (Ca) and Strontium (Sr) with up to $401 \mathrm{mg} / \mathrm{g}$ of $\mathrm{Ca}$ and $372 \mu \mathrm{g} / \mathrm{g}$ of $\mathrm{Sr}$ [23]. Eggshell comprises about $98 \%$ calcium carbonate and other trace elements such as magnesium and phosphorus. Shell membranes comprise $69.2 \%$ protein, $2.7 \%$ fat, $1.5 \%$ moisture and $27.2 \%$ ash. The membranes protein is about $10 \%$ collagen [21,24,25]. Beyond the elemental and oxide composition of eggshells, investigations into their biochemical and molecular component have been of great importance. The emergence of the chicken (Gallus gallus) genome sequence in 2004 created further success in understanding these components $[22,25,26]$.

The chicken eggshell further contains a complex matrix of proteins and carbohydrates. The amino acids (proteins) include ovalbumin, ovocleidin -17 , ovocleidin -116 , ovocalyxin -25 , ovocalyxin -32 , ovocalyxin - 36, osteopontin, clusterin, lysozyme, ovotransferrin, and collagen. Uronic acids, sialic acids, chondroitin sulfate A and B, dermatan sulfate, hyaluronic acids, and keratan sulfate are some of the polysaccharides (carbohydrates). 
Eggshells have been effectively used as fertilizer in agriculture, soil stabilizer in construction, calcium supplement construction, health, and medicine. Likewise, shell membrane collagen, when extracted, has diverse uses in the health, biochemical, pharmaceutical, food, and cosmetics industries. Collagen is a tough protein that connects and supports bodily tissues, such as skin, bone, tendons, muscles, and cartilage [27-31].

Collagen is mainly extracted from pigskin, cowhide, and bone skin. However, with the outbreak of mad cow disease, foot-and-mouth disease, autoimmune and allergic reactions, the use of collagen from these sources has been restricted. Eggshell membrane collagen has very low autoimmune and allergic reactions, high biological safety, and properties similar to other mammalian collagen. Eggshells and their membranes can be separated by various techniques, including chemical, mechanical, steam, microwave, and vacuum processes. [22,24,32].

Calcium oxide derived from the calcination of limestone has been proved responsible for the early strength development of concrete at room temperature. This is achieved by hydrating calcium oxide $(\mathrm{CaO})$ to form Calcium hydroxide causing the evolution of heat and, therefore, high early strength $[33,34]$. This process of decomposing limestone to form calcium oxide is responsible for $70 \%$ of the total $\mathrm{CO}_{2}$ generated at cement plants $[35,36]$.

An interesting observation is that calcium oxide can be produced through the calcination of the eggshells [30]. This avails a plausible substitute for lime in cement production while also halting the depletion of natural limestone resources and presenting the possibility of a significant reduction in the cement-linked high carbon footprint of the construction industry [37-39].

Against this backdrop, this research seeks to produce $\mathrm{CaO}$ from eggshells separated from its membrane by a chemical process as well as to recover substances leached from the shells during membrane separation. Leachate characterization was carried out with the use of UPLCMS and AA analysis, while XRD, XRF, RGB, TGA, and SEM analysis were used to aid microstructural characterization of the separated/unseparated shells and membrane.

This research is novel because it examines the recovery of eggshell membranes and other valuable compounds from the shell before calcinating the shells to produce $\mathrm{CaO}$ for the construction industry.

\section{Materials and Methods}

\subsection{Experimental methods.}

Eggshells were collected from eateries within the Hatfield surrounds, including the University of Pretoria, in Pretoria, South Africa. To decontaminate the shells, they were washed repeatedly in ultra-pure water, dried at $60^{\circ} \mathrm{C}$ for 60 minutes in an EcoTherm oven, and stored in plastic bags at room temperature within 24 hours of collection.

$1 \mathrm{M}$ acetic and nitric acid were used separately to leach the shells and aid membrane separation as outlined in [40]. Membrane separation was possible after 17 min of leaching; leaching was carried out for up to $60 \mathrm{~min}$. The separation was done by peeling off the membrane from its shell by hand.

Three groups of $20 \mathrm{~g}$ shells (unseparated, separated after 17 minutes, and separated after 60 minutes) were calcined using a Carbolite CWF1100 furnace in the presence of oxygen at 300, 500, 700, and 900 degrees for 30 minutes, 1 hour, 3 hours and 5 hours. Unseparated shells, shells separated after 17 minutes, and shells separated after 60 minutes are hereafter regarded as US, S17, and S60, respectively. 
To determine the leaching rate, $20 \mathrm{~g}$ of eggshells were leached in 13 sacrificial reactors containing $500 \mathrm{ml}$ of $1 \mathrm{~mol}$ Acetic acid each. After $\mathrm{pH}$ measurement, the entire contents of each reactor were sieved and washed with distilled water and dried to constant weight at $60{ }^{\circ} \mathrm{C}$. The $\mathrm{pH}$ of a 14th reactor was measured in parallel for $180 \mathrm{~min}$ to monitor the $\mathrm{CaCO}_{3}$ loss over time.

\subsection{Analytical methods.}

Instantaneous $\mathrm{pH}$ measurement was conducted to evaluate the rate at which $\mathrm{CaCO} 3$ and other shell constituents were leached into the acid medium. Looking specifically at the calcium concentration in the leached liquid, an atomic absorption spectrometer (AA) (Perkin Elmer AAnalyst 400, Waltham, Massachusetts) was used to measure calcium concentration in the leached liquid with an SJ hollow calcium lamp. $\mathrm{CaCl}_{2}$ was used to generate the standard linear calibration curve, while $1 \mathrm{M} \mathrm{KCl}$ was used to inhibit the ionization of $\mathrm{Ca}$ in water. The samples were diluted with ultra-pure water to the Ca concentration within the instrument's $5 \mathrm{mg} / 1$ linear range. The analysis was carried out using 3 different eggshell particle sizes for 17 and 60 minutes of soaking time.

Thermal analysis (TGA) was conducted to examine the change in mass with increased temperature during the calcination process. Image $\mathbf{J}$ software was also simultaneously used to monitor the change in color with an increase in temperature.

A scanning electron microscope (SEM) was used to understand the morphology of the calcined and uncalcined shells and membranes. Oxide compositions were obtained using Xray fluorescence $(\mathrm{XRF})$ analysis, while X-ray diffraction (XRD) was used to determine the mineralogy of the shells.

Ultra-performance-liquid chromatography quadrupole-time-of-flight mass spectrometry (UPLC-Q-TOF-MS) with MassLynx V4.1 software was used to identify collagen in the leachate.

\section{Results and Discussion}

\subsection{Physical properties.}

Results in Table 1 are inconsonant with the findings of [22,41]. The density was measured using the Archimedes principle. The reduced density is due to the removal of the highly porous membrane layer. However, this porosity is responsible for its use as a dye absorbent $[42,43]$.

Table 1. Characteristics of Eggshell and membrane.

\begin{tabular}{l|l} 
Characteristics & Value \\
\hline$\%$ Composition of the shell & $96.65 \%$ \\
\hline$\%$ Composition of the membrane & $3.35 \%$ \\
\hline Density of unseparated shell $\left(\mathrm{g} / \mathrm{cm}^{3}\right)$ & 2.01 \\
\hline Density of separated shell $\left(\mathrm{g} / \mathrm{cm}^{3}\right)$ & 1.53
\end{tabular}

\subsection{Effect of acid on shell membrane and calcium content.}

Acetic and nitric acid was used to weaken the bond between the shell and its membrane. Conversely, while the bond was weakened, eggshell calcium was gradually being leached into the acid medium. An atomic absorption spectrometer (AA) measured the calcium concentration 
in the leached liquid using 3 different eggshell particle sizes for 17 and 60 minutes of soaking time.

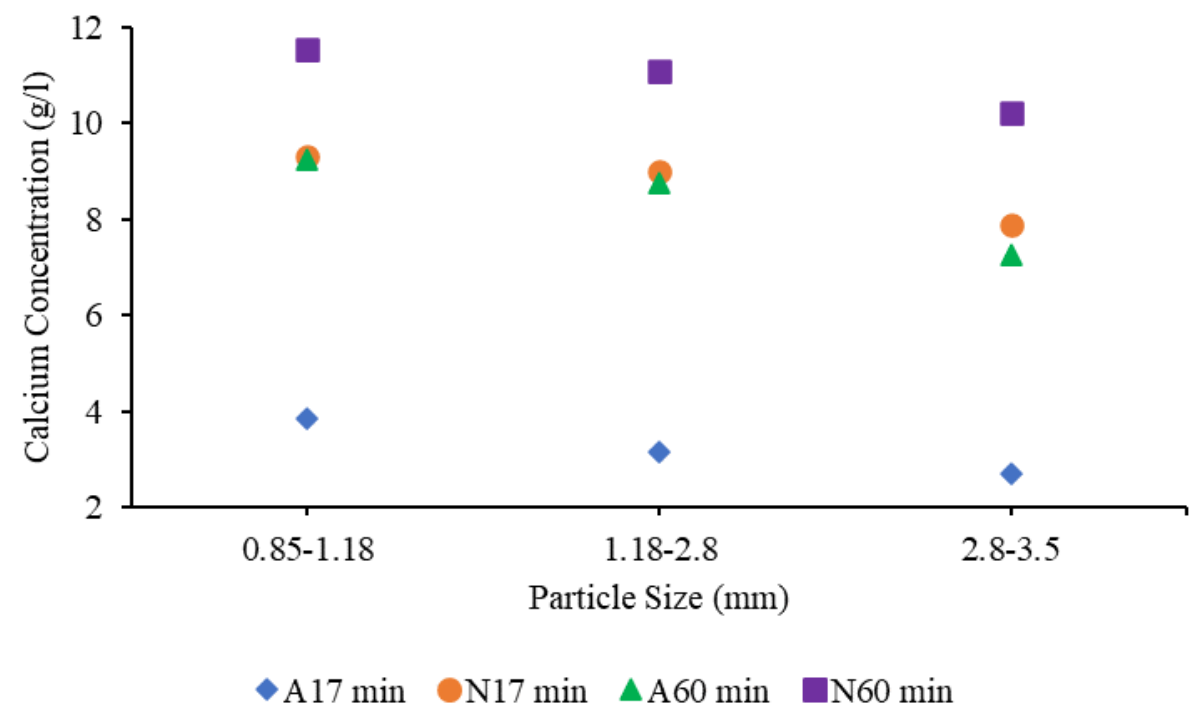

Figure 1. Calcium concentration in acid leachate.

(A17, acetic acid 17 minutes; N17, nitric acid 17 minutes; A60, acetic acid 60 minutes; N60, nitric acid 60 minutes).

It was evident that smaller particles released their calcium content much faster than bigger ones, as expected (Figure 1). In addition, nitric acid (N) leached as much as twice the amount of calcium leached by acetic acid (A). Due high leaching rate of nitric acid, acetic acid was adopted for further study. The AA analysis result was also corroborated by the experimental pH analysis in Figure 2. About $6 \mathrm{~g}(30 \%)$ and $15 \mathrm{~g}(75 \%)$ of $\mathrm{CaCO}_{3}$ were dissolved into the medium after 60 and 180 minutes of leaching, respectively.

Equation (1) depicts the model that governs the rate at which calcium is dissolved into the acidic medium. This gives an insight into the mass loss of $\mathrm{CaCO}_{3}$ during the leaching process for up to 180 minutes. The model is further explained in [40].

$$
\left[\mathrm{Ca}^{2+}\right]=\left[\mathrm{CO}_{3}^{2-}\right]+\left[\mathrm{HCO}_{3}^{-}\right]+\left[\mathrm{H}_{2} \mathrm{CO}_{3}\right]
$$

These results demonstrate that the amount of $\mathrm{CaCO}_{3}$ lost in the solution is the most significant limitation to the leaching method and agent for membrane removal [40]. This observation will be crucial in recommending an optimum leaching time.

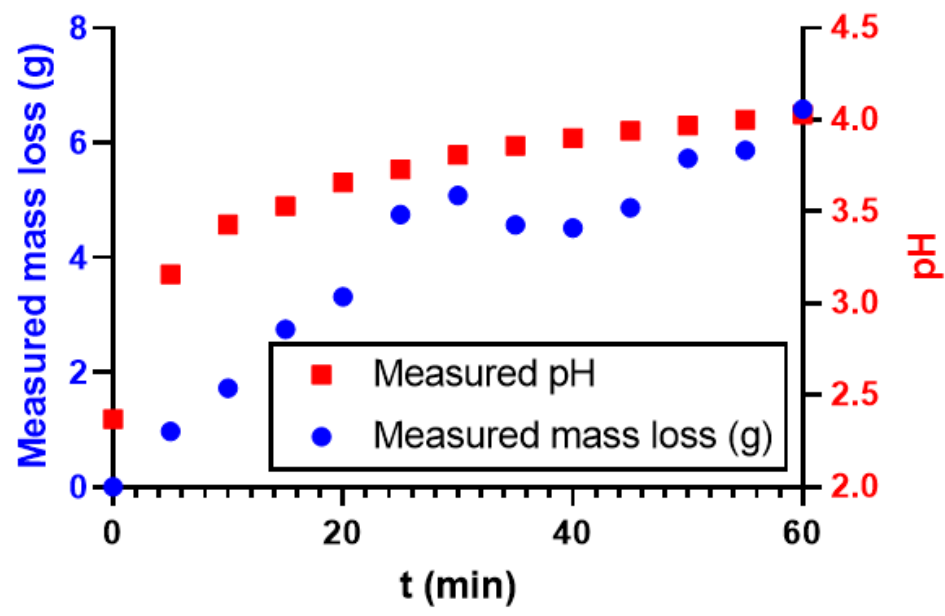

Figure 2. Change in $\mathrm{pH}$ and measured mass loss of eggshell in acetic acid. 


\subsection{Thermal analysis.}

A TGA5500 thermogravimetric analyzer was used to study the effect of increased temperature on the separated and unseparated eggshells and the shell membrane. The change in mass was measured with an increase in temperature from room temperature to $950{ }^{\circ} \mathrm{C}$ at a heating rate of $10^{\circ} \mathrm{C} / \mathrm{min}$ in the presence of nitrogen.

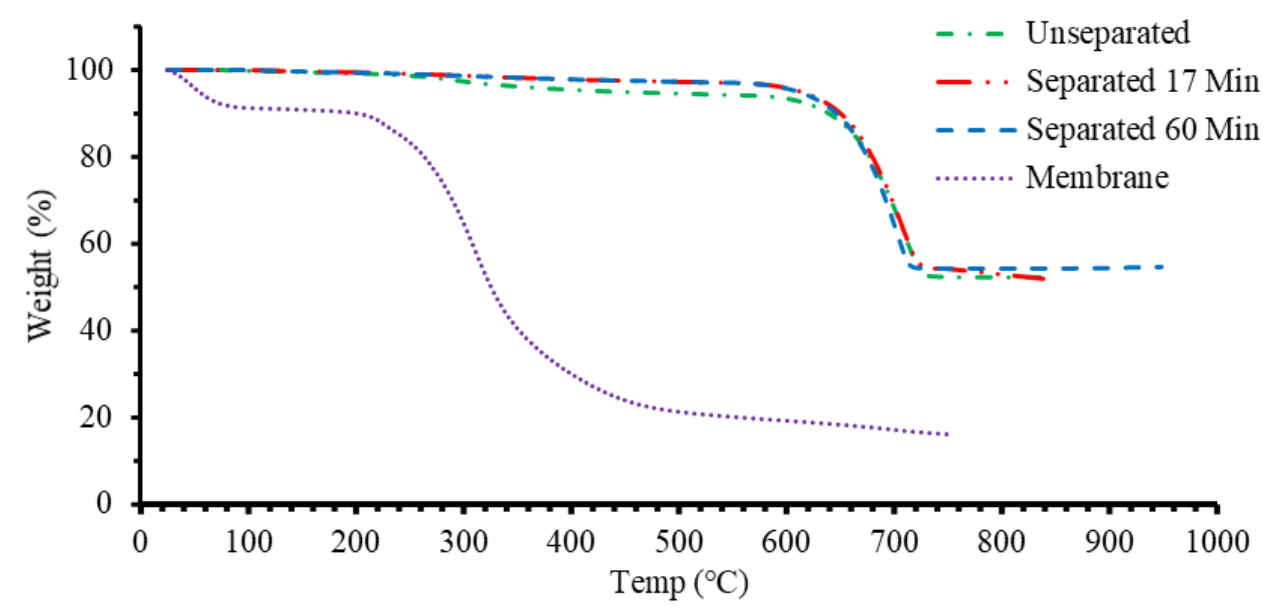

Figure 3. Thermogravimetric analysis.

(a) $300^{\circ} \mathrm{C}$

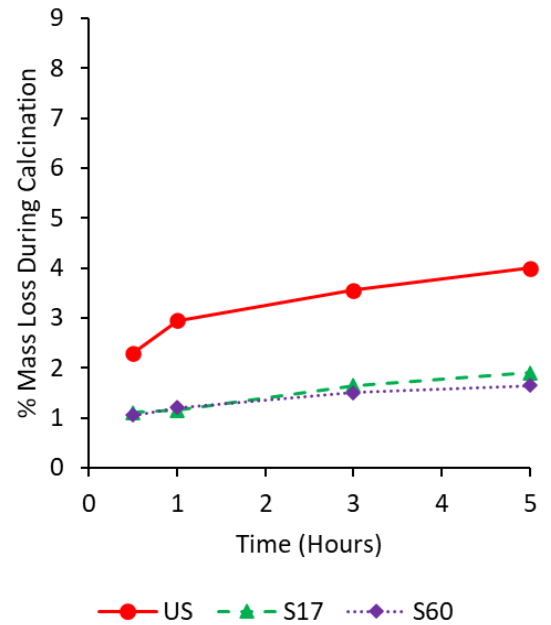

(c) $700^{\circ} \mathrm{C}$

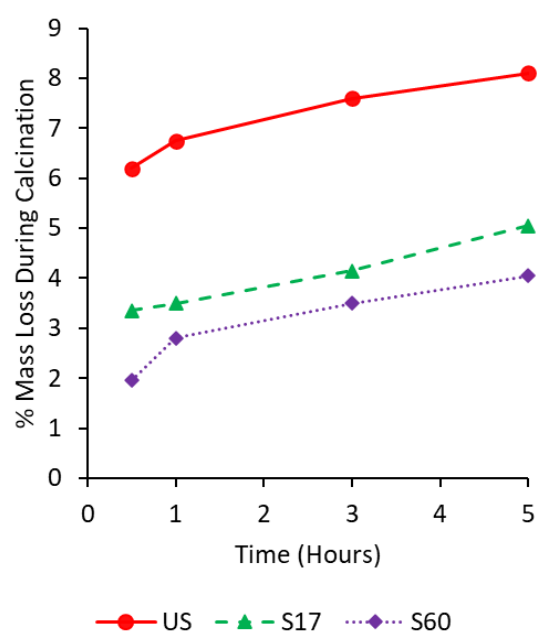

(b) $500^{\circ} \mathrm{C}$

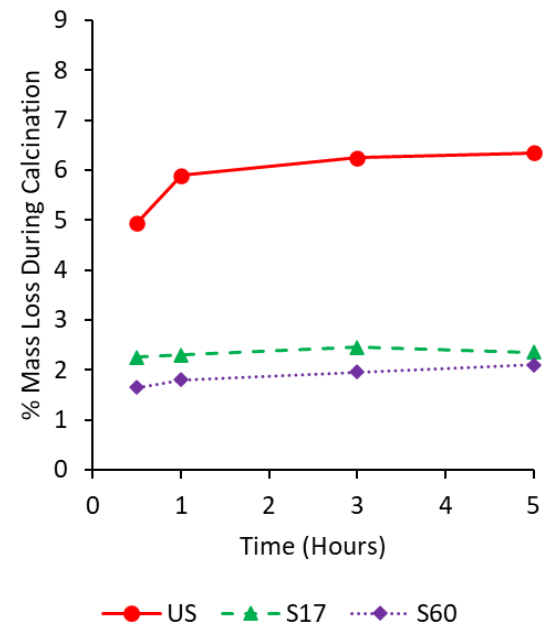

(d) $900^{\circ} \mathrm{C}$

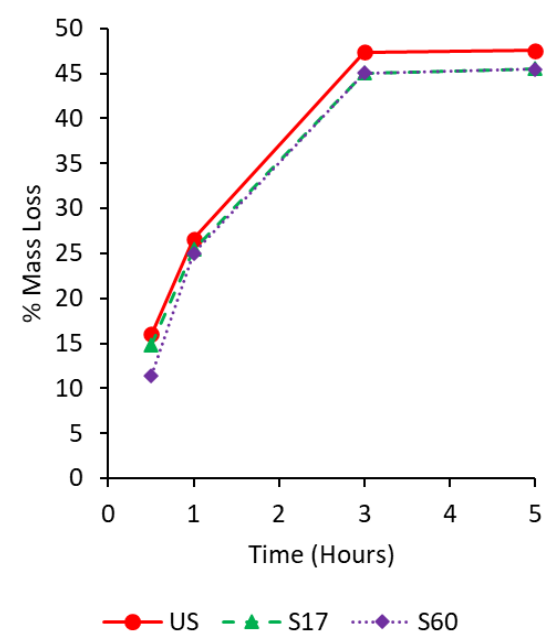

Figure 4. Calcination analysis. 
Thermal analysis plots comprising of the TG spectra of US, S17, and S60 shells, as well as the membrane, are seen in Figure 3. The three shell samples began with a linear reduction in weight due to loss of moisture up to $300^{\circ} \mathrm{C}$, after which US samples record a nonlinear reduction due to the volatilization of its membrane constituent. All shells samples continued the linear path until about $650^{\circ} \mathrm{C}$, at which point the shells' water, protein, and carbon constituents are evaporated, and actual calcination sets in. The plot shows that separated shells were fully calcined at about $720^{\circ} \mathrm{C}$, while unseparated shells became fully calcined at $735^{\circ} \mathrm{C}$. On the other hand, the shell membrane, which is less dense than the shells, turns completely into ash after $300{ }^{\circ} \mathrm{C}$, leaving approximately $10 \%$ weight at $>700^{\circ} \mathrm{C}$, which eventually becomes a potential source of impurities in the US samples.

(a) $300^{\circ} \mathrm{C}$

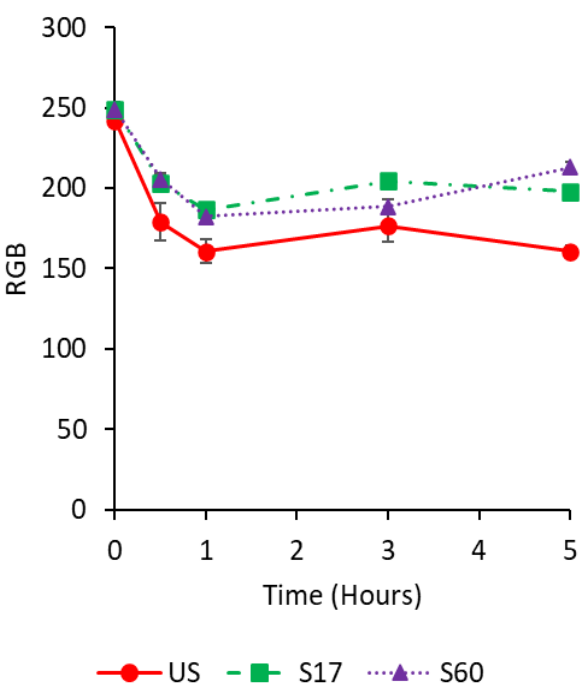

(c) $700^{\circ} \mathrm{C}$

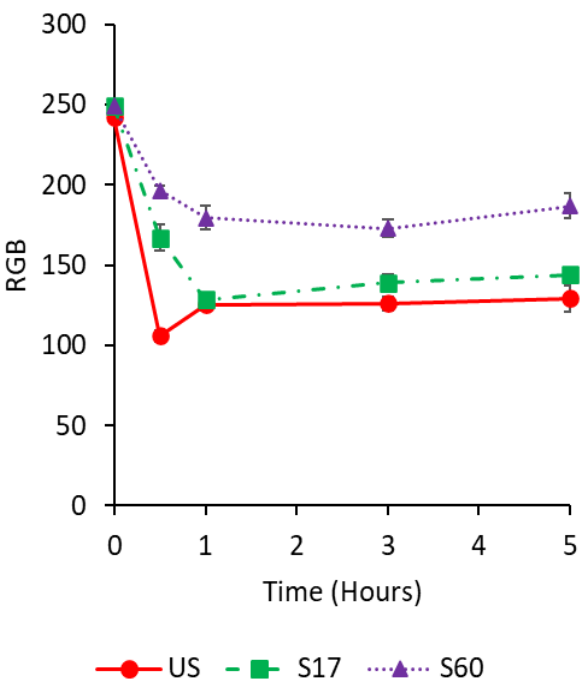

(b) $500^{\circ} \mathrm{C}$

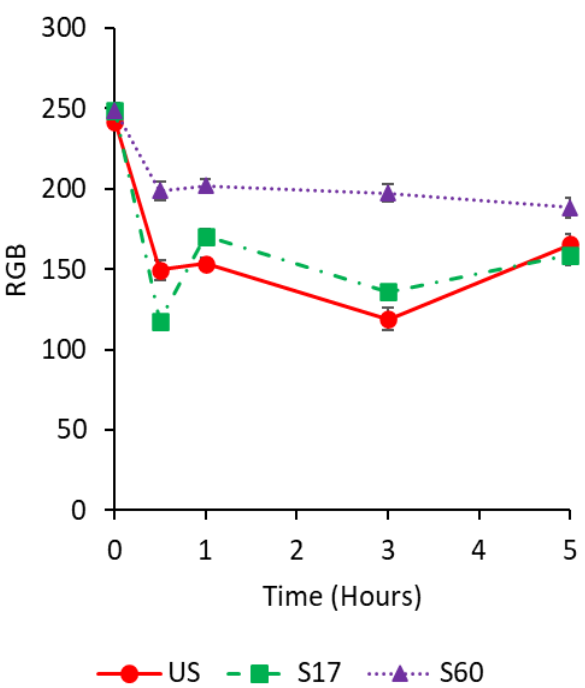

(d) $900^{\circ} \mathrm{C}$

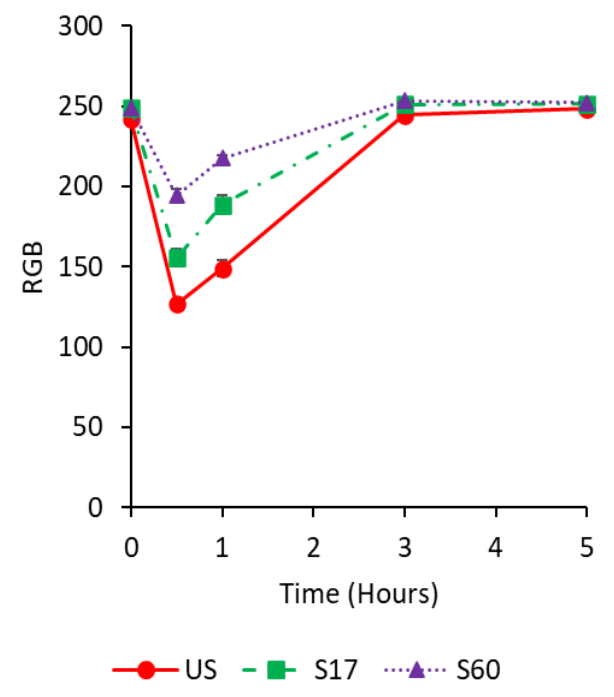

Figure 5. RGB color analysis.

Calcination was carried out in a carbolite CWF1100 furnace at 300, 500, 700, and 900 degrees for 30 minutes, 1 hour, 3 hours, and 5 hours. Mass loss with an increase in temperature was recorded and plotted in Figure 4. (a), (b), and (c) logged a wide difference between the leached and unseparated samples. This is due to the presence of shell membrane, which burns out faster in the unseparated samples. Nevertheless, this disparity was largely decreased at $900^{\circ} \mathrm{C}$ with the formation of membrane ash. Unseparated shells had a $47 \%$ mass loss, while 
separated samples lost $45 \%$ of their initial mass. This is consistent with readings from the TGA analysis.

While calcination was carried out, Image $\mathrm{J}$ was used to conduct an RGB color analysis of the calcined shells. Pictures of the calcined shells were taken with a 13-megapixel camera at a constant distance and illumination. Due to the addictive nature of the three-color spectrum, the red values were recorded and used for analysis as plotted in Figure 5.

The data revealed the trend of color change from brown at $300{ }^{\circ} \mathrm{C}$ to dark brown, grey, and finally white at $900{ }^{\circ} \mathrm{C}$ [41]. It was also detected that the samples leached for 60 minutes did not get as dark as much as the raw samples, and those leached for 17 minutes. This can be due to the reduced carbon content of the S60 samples. All three categories of samples attained a constant white color spectrum after 3 hours of calcination. The lack of white color at $700{ }^{\circ} \mathrm{C}$ and the result of the XRD analysis imply that calcination was only optimum at $900{ }^{\circ} \mathrm{C}[41,44]$. S17 samples were observed to behave similarly to S60 samples while calcination was complete after 3 hours. Therefore, leaching beyond 17 minutes and more than 3 hours of calcination seems not to aid calcination.

\subsection{Microstructural analysis.}

The morphology of the shell and membrane samples was studied in a Zeiss Ultra PLUS FEG scanning electron microscope (SEM). Samples were dried before being sputter-coated with carbon in a Quorum Q150T ES coater for imaging. As seen in Figure 6 (a-c), the morphology results disclosed that the eggshell is porous, crystalline in nature, and characterized by an angular pattern. The formation of agglomerates was also observed [45]. $\mathrm{CaO}$, on the other hand, as spotted in (d-f), exhibits a honeycomb-like porous surface with rodlike particles [46,47]. SEM image of the shell membrane revealed that the membrane has an enormous surface with fiber-like pores. This porous fibril structure makes the shell membrane a good adsorbing agent [48].

The oxide composition of shells calcined at $900{ }^{\circ} \mathrm{C}$ for 3 hours was investigated by $\mathrm{X}$ ray Florescence (XRF) analysis and outlined in Table 2. The Thermo Fisher ARL Perform'X Sequential instrument with Uniquant software was employed. The samples were roasted in alumina refractory crucibles at $1000{ }^{\circ} \mathrm{C}$ to determine Loss of Ignition (LOI). $1 \mathrm{~g}$ roasted sample was then placed with $6 \mathrm{~g}$ of $\mathrm{Li}_{2} \mathrm{~B}_{4} \mathrm{O}_{7}$ into a Pt/Au crucible and fused into a glass bead at $1050^{\circ} \mathrm{C}$. The software analyzed for all elements in the periodic table between $\mathrm{Na}$ and $\mathrm{U}$, but only elements above the detection limits were reported. The results were normalized to include LOI for the sample to indicate crystal water and/or oxidation state changes. Blank and certified reference materials are analyzed with each batch of samples.

Table 2. Oxide composition of the calcinated shell.

\begin{tabular}{l|c|c|c} 
Oxides & US & S17 & S60 \\
\hline $\mathrm{MgO}$ & 1.366 & 1.279 & 1.138 \\
\hline $\mathrm{P}_{2} \mathrm{O}_{5}$ & 0.618 & 0.419 & 0.416 \\
\hline $\mathbf{C a O}$ & $\mathbf{9 7 . 4 3 5}$ & $\mathbf{9 7 . 6 6 3}$ & $\mathbf{9 7 . 7 0 0}$ \\
\hline $\mathrm{SO}_{3}$ & 0.023 & 0.039 & 0.052 \\
\hline $\mathrm{SrO}$ & 0.025 & 0.021 & 0.022 \\
\hline $\mathrm{BaO}$ & 0.237 & 0.211 & 0.256
\end{tabular}

Oxide composition from the XRF analysis in Table 2 and the XRD quantitative analysis results in Figure 7 gave similar $\mathrm{CaO}$ composition data to be about $98 \%$ after 17 minutes soaking 
time and 3 hours of calcination. Calcination therefore, effectively transforms $\mathrm{CaCO}_{3}$ into $\mathrm{CaO}$ $[41,44]$.
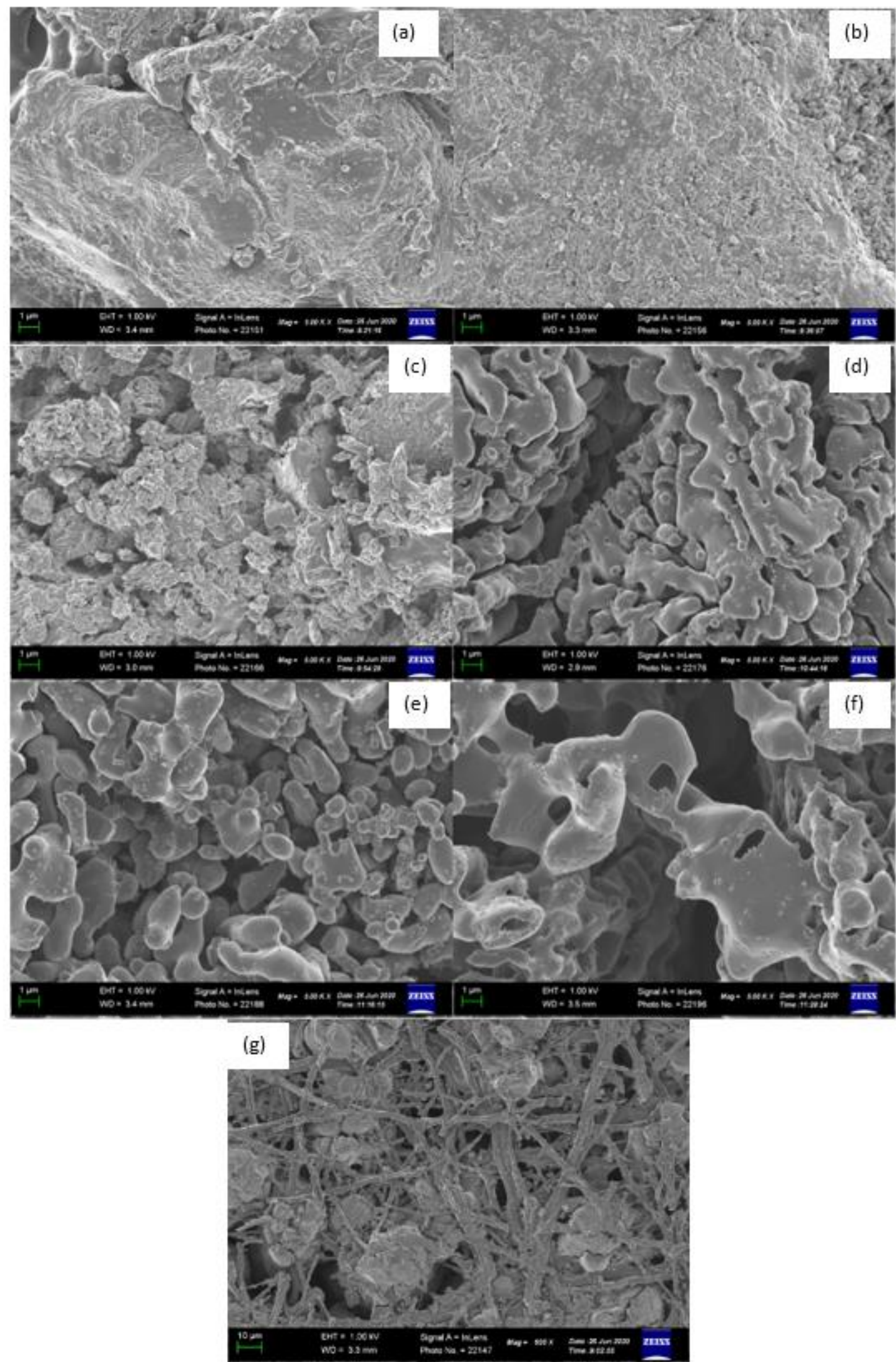

Figure 6. SEM image of eggshell, $\mathrm{CaO}$, and membrane. (a)US shells, (b) S17 shells, (c) S60 shells, (d) US CaO, (e) $\mathrm{S} 17 \mathrm{CaO}$, (f) $\mathrm{S} 60 \mathrm{CaO}$, (g) membrane.

X-ray diffraction (XRD) analysis was used to determine the mineralogy of the shells before and after calcination. The samples were prepared according to the standardized https://biointerfaceresearch.com/ 
Panalytical post-loading system, which provides a nearly random particle distribution. The PANalytical X'Pert Pro powder diffractometer was used to analyze the sample in the $\theta-\theta$ configuration, which is equipped with an $\mathrm{X}$ Celerator detector and variable divergence and fixed receiver tank, with Fe filtered $\mathrm{CoK} \alpha$ radiation $(\lambda=1,789 \AA)$. The mineralogy is determined using the $X^{\prime}$ Pert Highscore plus software to select the most suitable pattern for measuring the diffraction pattern from the ICSD database. The relative amount of phase (weight $\%$ of the crystalline part) was estimated using the Rietveld method by utilizing the basic parameter method of the Autoquan/BGMN software.

Figure 7 and Figure 8 exemplify the transformation of $\mathrm{CaCO}_{3}$ in uncalcined shells to $\mathrm{CaO}$ after 3 hours of calcination. Uncalcined shells were characterized by peaks of $\mathrm{CaCO}_{3}$, though; unseparated shells showed slightly higher peaks than separated ones. After calcination, peaks of $\mathrm{CaO}$ were observed. Due to the hygroscopic nature of $\mathrm{CaO}$, faint peaks of portlandite, $\mathrm{Ca}(\mathrm{OH})_{2}$ were identified. Soaking time had no significance in the formation of $\mathrm{CaO}$ in $\mathrm{S} 17$ and S60 samples.

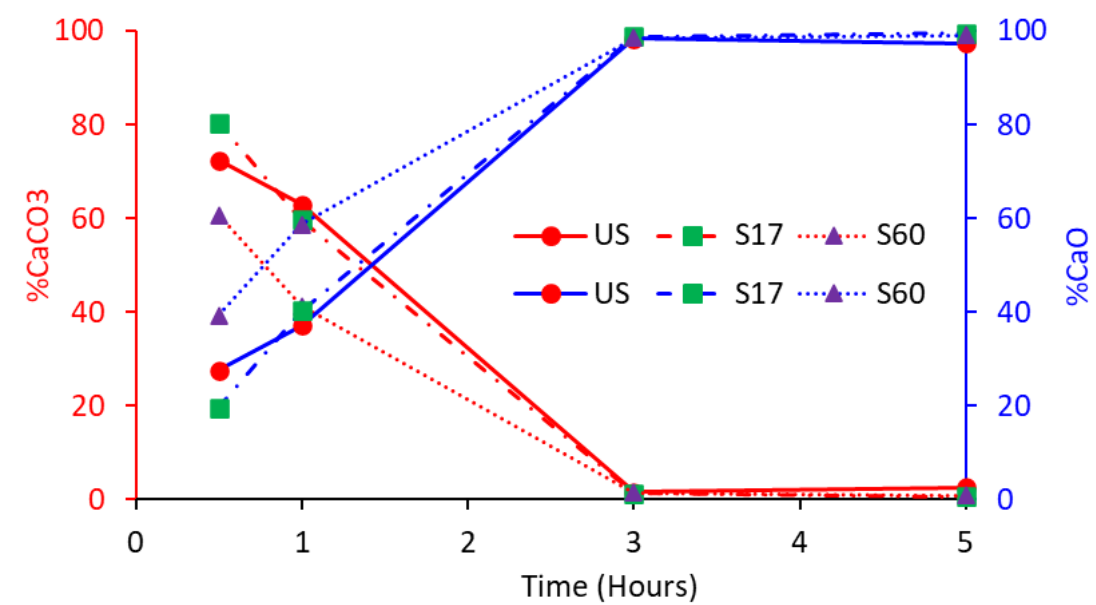

Figure 7. XRD quantitative analysis.

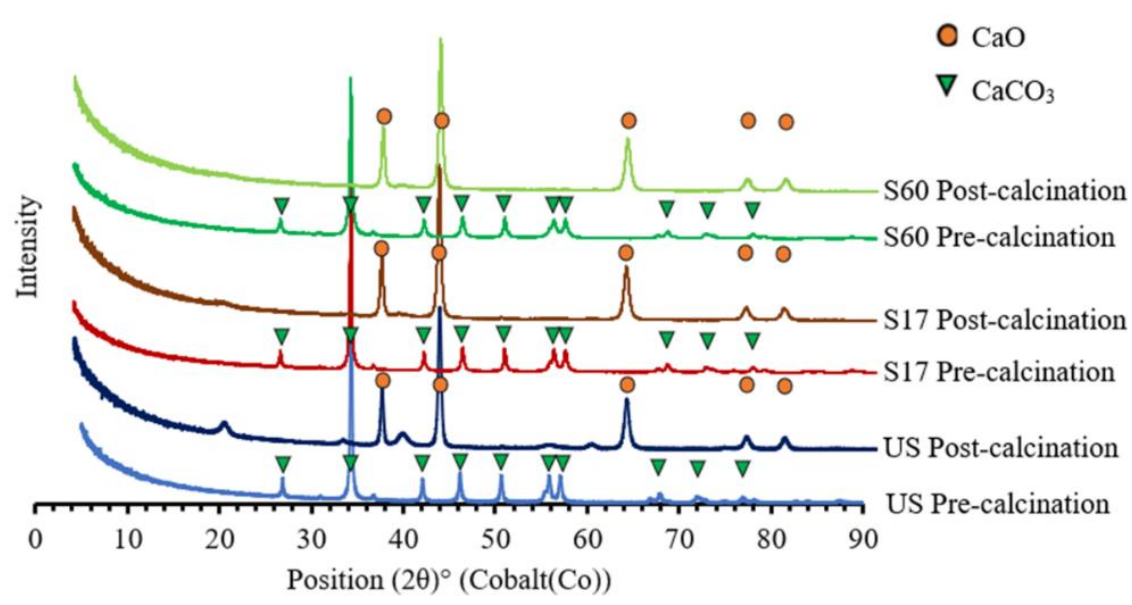

Figure 8. XRD pattern of eggshell before and after calcination.

\subsection{Recovery of collagen and other compounds.}

UPLC was performed using a Waters Acquity UPLC system (Waters Corp., MA USA) equipped with a binary solvent delivery system and an autosampler. The Waters Synapt G2 high-resolution QTOF mass spectrometer equipped with an ESI source is used to acquire negative and positive ion data. The system was powered by MassLynx V 4.1 software (Waters 
Inc., Milford, Massachusetts, USA) for data acquisition. By generating molecular formulas from MassLynx V 4.1 based on iFit values and comparing MS / MS fragmentation patterns with matching compounds from the PubChem, ChemSpider, and Massbank libraries, the compounds were initially identified. Furthermore, the precise masses obtained are compared with the precise masses of known compounds in the compound database.

All the compounds listed in Table 3 were identified in Nitric acid-leached shells while, compounds 6, 8, and 11 were not identified in shells leached with acetic acid. This can be associated with the already observed high leaching power of nitric acid. It should however be noted that other forms of these compounds $(5,7,10)$ were identified in acetic and nitric acid leached shells.

Collagen was identified in both S17 and S60 samples in both positive and negative modes. Three forms of collagen were observed as in Table 3. This illustrates the possibility of recovering eggshell collagen and other valuable compounds before calcining the shell for $\mathrm{CaO}$.

\begin{tabular}{|c|c|c|c|c|c|c|}
\hline S/No & Name & $\begin{array}{l}\text { Molecular } \\
\text { formula }\end{array}$ & $\begin{array}{c}\text { Molecular } \\
\text { mass, }(\mathrm{g} / \mathrm{mol})\end{array}$ & $\begin{array}{c}\text { Presence in Nitric } \\
\text { acid leached effluent }\end{array}$ & $\begin{array}{c}\text { Presence in Acetic acid } \\
\text { leached effluent }\end{array}$ & Reference \\
\hline 1 & Collagen & $\mathrm{C}_{8} \mathrm{H}_{7} \mathrm{FO}_{3}$ & 170.1378 & + & + & [49] \\
\hline 2 & $\begin{array}{l}\text { Collagen } \\
\text { ointment }\end{array}$ & $\mathrm{C}_{18} \mathrm{H}_{28} \mathrm{~N}_{2} \mathrm{O}$ & 288.4277 & + & + & {$[50]$} \\
\hline 3 & $\begin{array}{l}\text { Collagen (type II } \\
\text { fragment) }\end{array}$ & $\mathrm{C}_{13} \mathrm{H}_{24} \mathrm{~N}_{4} \mathrm{O}_{4}$ & 300.3541 & + & + & {$[51,52]$} \\
\hline 4 & lysozyme & $\mathrm{C}_{36} \mathrm{H}_{61} \mathrm{~N}_{7} \mathrm{O}_{19}$ & 895.4022 & + & + & [53] \\
\hline 5 & Uronic acid & $\mathrm{C}_{6} \mathrm{H}_{11} \mathrm{NO}_{6}$ & 193.0586 & + & + & [54] \\
\hline 6 & Uronic acid & $\mathrm{C}_{12} \mathrm{H}_{17} \mathrm{Cl}_{3} \mathrm{O}_{9}$ & 411.6170 & + & - & [55] \\
\hline 7 & Sialic acid & $\mathrm{C}_{11} \mathrm{H}_{19} \mathrm{NO}_{9}$ & 309.2699 & + & + & [56] \\
\hline 8 & Sialic acid & $\mathrm{C}_{20} \mathrm{H}_{36} \mathrm{~N}_{2} \mathrm{O}_{17}$ & 576.5030 & + & - & [57] \\
\hline 9 & $\begin{array}{l}\text { Chondroitin } \\
\text { sulphate A }\end{array}$ & $\mathrm{C}_{14} \mathrm{H}_{23} \mathrm{NO}_{15} \mathrm{~S}$ & 477.3951 & + & + & [58] \\
\hline 10 & $\begin{array}{l}\text { Dermatan } \\
\text { sulphate }\end{array}$ & $\mathrm{C}_{14} \mathrm{H}_{21} \mathrm{NO}_{15} \mathrm{~S}^{-2}$ & 475.3792 & + & + & [59] \\
\hline 11 & $\begin{array}{l}\text { Dermatan } \\
\text { sulphate }\end{array}$ & $\mathrm{C}_{18} \mathrm{H}_{31} \mathrm{NO}_{14} \mathrm{~S}$ & 517.5020 & + & - & {$[60]$} \\
\hline 12 & Hyaluronic acid & $\mathrm{C}_{33} \mathrm{H}_{54} \mathrm{~N}_{2} \mathrm{O}_{23}$ & 846.7815 & + & + & [61] \\
\hline 13 & Keratan sulphate & $\mathrm{C}_{28} \mathrm{H}_{48} \mathrm{~N}_{2} \mathrm{O}_{32} \mathrm{~S}_{4}$ & 1052.9349 & + & + & [62] \\
\hline
\end{tabular}

\section{Conclusions}

The evidence provided in this article has shown that firstly, Acetic acid efficiently weakened the bond between the eggshell and its membrane instead of nitric acid, thereby aiding membrane separation. Similarly, 17 minutes of soaking time was sufficient to minimize the loss of calcium in the solution. Membrane separation before calcination valorizes the eggshell as the membrane can be put to more beneficial use. Secondly, the leaching and membrane separation process does not impair the quality of $\mathrm{CaO}$ produced after calcination; instead, it validates it as carbonaceous membrane impurities have been eliminated. Finally, collagen and other compounds identified in the leachate motivate more research on how these can be most efficiently salvaged before calcination.

\section{Funding}

This work was supported by the National Research Foundation (NRF) of South Africa and The World Academy of Science (TWAS) under grant number 116102. 


\section{Acknowledgments}

\section{The authors kindly acknowledge the LC-MS Synapt Facility (Department of Chemistry, University of Pretoria) for chromatography and mass spectrometry services provided by Ms. Madelien Wooding.}

\section{Conflicts of Interest}

The authors declare no conflict of interest.

\section{References}

1. Nhamo, G.; Mjimba, V. Biting the Hand That Feeds You: Green Growth and Electricity Revenues in South African Metropolitans. Public Munic. Financ. 2014, 3, 19-31.

2. Fu, L.; Cao, Y.; Kuang, S.-Y.; Guo, H. Index for Climate Change Adaptation in China and Its Application. Adv. Clim. Chang. Res. 2021, https://doi.org/10.1016/j.accre.2021.06.006.

3. Simonson, W.D.; Miller, E.; Jones, A.; García-Rangel, S.; Thornton, H.; McOwen, C. Enhancing Climate Change Resilience of Ecological Restoration - A Framework for Action. Perspect. Ecol. Conserv. 2021, 19, 300-310, https://doi.org/10.1016/j.pecon.2021.05.002.

4. Antwi-Agyei, P.; Wiafe, E.A.; Amanor, K.; Baffour-Ata, F.; Codjoe, S.N.A. Determinants of Choice of Climate Change Adaptation Practices by Smallholder Pineapple Farmers in the Semi-Deciduous Forest Zone of Ghana. Environ. Sustain. Indic. 2021, 12, https://doi.org/10.1016/j.indic.2021.100140.

5. Ellen MacArthur Foundation Towards the Circular Economy - Economic and Business Rationale for an Accelerated Transition. Greener Manag. Int. 2012, 1, 1-13.

6. Deus, R.M.; Mele, F.D.; Bezerra, B.S.; Battistelle, R.A.G. A Municipal Solid Waste Indicator for Environmental Impact: Assessment and Identification of Best Management Practices. J. Clean. Prod. 2020, 242, https://doi.org/10.1016/j.jclepro.2019.118433.

7. Christensen, T.B. Towards a Circular Economy in Cities: Exploring Local Modes of Governance in the Transition towards a Circular Economy in Construction and Textile Recycling. J. Clean. Prod. 2021, 305, https://doi.org/10.1016/j.jclepro.2021.127058.

8. Petković, B.; Agdas, A.S.; Zandi, Y.; Nikolić, I.; Denić, N.; Radenkovic, S.D.; Almojil, S.F.; Roco-Videla, A.; Kojić, N.; Zlatković, D.; et al. Neuro Fuzzy Evaluation of Circular Economy Based on Waste Generation, Recycling, Renewable Energy, Biomass and Soil Pollution. Rhizosphere 2021, 19, https://doi.org/10.1016/j.rhisph.2021.100418.

9. Embong, R.; Shafiq, N.; Kusbiantoro, A.; Nuruddin, M.F. Effectiveness of Low-Concentration Acid and Solar Drying as Pre-Treatment Features for Producing Pozzolanic Sugarcane Bagasse Ash. J. Clean. Prod. 2016, 112, 953-962, https://doi.org/10.1016/j.jclepro.2015.09.066.

10. Part, W.K.; Ramli, M.; Cheah, C.B. An Overview on the Influence of Various Factors on the Properties of Geopolymer Concrete Derived From Industrial Byproducts. Handb. Low Carbon Concr. 2016, 77, 263-334, https://doi.org/10.1016/B978-0-12-804524-4.00011-7.

11. Albino, V.; Berardi, U.; Dangelico, R.M. Smart Cities: Definitions, Dimensions, Performance, and Initiatives. J. Urban Technol. 2015, 22, 3-21, https://doi.org/10.1080/10630732.2014.942092.

12. Alao, M.A.; Popoola, O.M.; Ayodele, T.R. Selection of Waste-to-Energy Technology for Distributed Generation Using IDOCRIW-Weighted TOPSIS Method: A Case Study of the City of Johannesburg, South Africa. Renew. Energy 2021, 178, 162-183, https://doi.org/https://doi.org/10.1016/j.renene.2021.06.031.

13. Ayeleru, O.O.; Fajimi, L.I.; Oboirien, B.O.; Olubambi, P.A. Forecasting Municipal Solid Waste Quantity Using Artificial Neural Network and Supported Vector Machine Techniques: A Case Study of Johannesburg, South Africa. J. Clean. Prod. 2021, 289, https://doi.org/10.1016/j.jclepro.2020.125671.

14. Kaza, S.; Yao, L.; Bhada-Tata, P.; Van Woerden, F. What a Waste 2.0: A Global Snapshot of Solid Waste Management to 2050; The World Bank: Washington, DC, 2018.

15. Department of Environmental Affairs South Africa State of Waste Report South Africa First Draft Report. Gov. South Africa 2018, 68.

16. Oliveira, D.A.; Benelli, P.; Amante, E.R. A Literature Review on Adding Value to Solid Residues: Egg Shells. J. Clean. Prod. 2013, 46, 42-47, https://doi.org/10.1016/j.jclepro.2012.09.045.

17. Statista Global Egg Production from 1990 to 2018 Available online: https://www.statista.com/statistics/263972/egg-production-worldwide-since-1990/ (accessed on 19 April 2020).

18. South African Poultry Association Egg Industry Production Report for November 2019, 2019.

19. Frank, H.J. About the authors. Government Information Quarterly 2006, 23, 159-161, https://doi.org/10.1016/j.giq.2006.04.004. 
20. Geissdoerfer, M.; Savaget, P.; Bocken, N.M.P.; Hultink, E.J. The Circular Economy - A New Sustainability Paradigm? J. Clean. Prod. 2017, 143, 757-768.

21. Nakano, T.; Ikawa, N.I.; Ozimek, L. Chemical Composition of Chicken Eggshell and Shell Membranes. Poult. Sci. 2003, 82, 510-514, https://doi.org/10.1093/ps/82.3.510.

22. Hussain, A. Dielectric Properties and Microwave Assisted Separation of Eggshell and Membrane. McGill University Ste Anne De Bellevue, Quebec, Canada, 2009.

23. Schaafsma, A.; Pakan, I.; Hofstede, G.J.H.; Muskiet, F.A.J.; Van Der Veer, E.; De Vries, P.J.F. Mineral, Amino Acid, and Hormonal Composition of Chicken Eggshell Powder and the Evaluation of Its Use in Human Nutrition. Poult. Sci. 2000, 79, 1833-1838, https://doi.org/10.1093/ps/79.12.1833.

24. King'ori, A.M. A Review of the Uses of Poultry Eggshells and Shell Membranes. Int. J. Poult. Sci. 2011, 10, 908-912, https://doi.org/10.3923/ijps.2011.908.912.

25. Hincke, M.T.; Nys, Y.; Gautron, J.; Mann, K.; Rodriguez-Navarro, A.B.; McKee, M.D. The Eggshell: Structure, Composition and Mineralization. Front. Biosci. 2012, 17, 1266-1280, https://doi.org/10.2741/3985.

26. Rose, M.L.H.; Hincke, M.T. Protein Constituents of the Eggshell: Eggshell-Specific Matrix Proteins. Cell. Mol. Life Sci. 2009, 66, 2707-2719, https://doi.org/10.1007/s00018-009-0046-y.

27. Saldanha, R.B.; da Rocha, C.G.; Caicedo, A.M.L.; Consoli, N.C. Technical and Environmental Performance of Eggshell Lime for Soil Stabilization. Constr. Build. Mater. 2021, 298, https://doi.org/10.1016/j.conbuildmat.2021.123648.

28. Vandeginste, V. Food Waste Eggshell Valorization through Development of New Composites: A Review. Sustain. Mater. Technol. 2021, 29, https://doi.org/10.1016/j.susmat.2021.e00317.

29. Zain, M.R.; Oh, C.L.; Lee, S.W. Investigations on Rheological and Mechanical Properties of SelfCompacting Concrete (SCC) Containing 0.6 Mm Eggshell as Partial Replacement of Cement. Constr. Build. Mater. 2021, 303, https://doi.org/10.1016/j.conbuildmat.2021.124539.

30. Hsieh, S.-L.; Li, F.-Y.; Lin, P.-Y.; Beck, D.E.; Kirankumar, R.; Wang, G.-J.; Hsieh, S. CaO Recovered from Eggshell Waste as a Potential Adsorbent for Greenhouse Gas CO2. J. Environ. Manage. 2021, 297, https://doi.org/10.1016/j.jenvman.2021.113430.

31. Bharti, R.; Guldhe, A.; Kumar, D.; Singh, B. Solar Irradiation Assisted Synthesis of Biodiesel from Waste Cooking Oil Using Calcium Oxide Derived from Chicken Eggshell. Fuel 2020, 273, https://doi.org/10.1016/j.fuel.2020.117778.

32. Krongkitsiri, P.; Krongkitsiri, W.; Phukird, S.; Tipparach, U. A Comparison of Dielectric Properties of Eggshells from Free-Range System and Control-Range System. Mater. Today Proc. 2021, https://doi.org/10.1016/j.matpr.2021.05.091.

33. Ng, C.; Alengaram, U.J.; Wong, L.S.; Mo, K.H.; Jumaat, M.Z.; Ramesh, S. A Review on Microstructural Study and Compressive Strength of Geopolymer Mortar, Paste and Concrete. Constr. Build. Mater. 2018, 186, 550-576, https://doi.org/10.1016/j.conbuildmat.2018.07.075.

34. Ige, J.A.; Anifowose, M.A.; Amototo, I.O.; Adeyemi, A.O.; Olawuyi, M.Y. Influence of Groundnut Shell Ash (GSA) and Calcium Chloride $(\mathrm{CaCl} 2)$ on Strength of Concrete. Ann. Fac. Eng. Hunedoara - Int. J. Eng. 2017, 15, 209-214.

35. Rodriguez, N.; Alonso, M.; Abanades, J.C.; Grasa, G.; Murillo, R. Analysis of a Process to Capture the CO2 Resulting from the Pre-Calcination of the Limestone Feed to a Cement Plant. Energy Procedia 2009, 1, 141148, https://doi.org/10.1016/j.egypro.2009.01.021.

36. Sathiparan, N. Utilization Prospects of Eggshell Powder in Sustainable Construction Material - A Review. Constr. Build. Mater. 2021, 293, https://doi.org/10.1016/j.conbuildmat.2021.123465.

37. Razali, N.; Azizan, M.A.; Pa'ee, K.F.; Razali, N.; Jumadi, N. Preliminary Studies on Calcinated Chicken Eggshells as Fine Aggregates Replacement in Conventional Concrete. Mater. Today Proc. 2020, 31, 354359, https://doi.org/10.1016/j.matpr.2020.06.232.

38. Hamada, H.M.; Tayeh, B.A.; Al-Attar, A.; Yahaya, F.M.; Muthusamy, K.; Humada, A.M. The Present State of the Use of Eggshell Powder in Concrete: A Review. J. Build. Eng. 2020, 32, https://doi.org/10.1016/j.jobe.2020.101583.

39. Chong, B.W.; Othman, R.; Ramadhansyah, P.J.; Doh, S.I.; Li, X. Properties of Concrete with Eggshell Powder: A Review. Phys. Chem. Earth, Parts A/B/C 2020, 120, https://doi.org/10.1016/j.pce.2020.102951.

40. Aina, S.T.; Du-Plessis, B.J.; Mjimba, V.; Brink, H.G. Effect of Membrane Removal on The Production of Calcium Oxide from Eggshells Via Calcination. Chem. Eng. Trans. 2020, 81, 1069-1074, https://doi.org/10.3303/CET2081179.

41. Tangboriboon, N.; Kunanuruksapong, R.; Sirivat, A.; Kunanuruksapong, R.; Sirivat, A. Preparation and Properties of Calcium Oxide from Eggshells via Calcination. Mater. Sci. Pol. 2012, 30, 313-322, https://doi.org/10.2478/s13536-012-0055-7.

42. Murcia-Salvador, A.; Pellicer, J.A.; Rodríguez-López, M.I.; Gómez-López, V.M.; Núñez-Delicado, E.; Gabaldón, J.A. Egg By-Products as a Tool to Remove Direct Blue 78 Dye from Wastewater: Kinetic, Equilibrium Modeling, Thermodynamics and Desorption Properties. Materials (Basel). 2020, 13, https://doi.org/10.3390/ma13061262. 
43. Tsai, W.T.; Yang, J.M.; Lai, C.W.; Cheng, Y.H.; Lin, C.C.; Yeh, C.W. Characterization and Adsorption Properties of Eggshells and Eggshell Membrane. Bioresour. Technol. 2006, 97, 488-493, https://doi.org/10.1016/j.biortech.2005.02.050.

44. Mohadi, R.; Anggraini, K.; Riyanti, F.; Lesbani, A. Preparation Calcium Oxide From Chicken Eggshells. Sriwij. J. Environ. 2016, 1, 32-35, https://doi.org/10.22135/sje.2016.1.2.32-35.

45. Zulfikar, M.A.; Novita, E.; Hertadi, R.; Djajanti, S.D. Removal of Humic Acid from Peat Water Using Untreated Powdered Eggshell as a Low Cost Adsorbent. Int. J. Environ. Sci. Technol. 2013, 10, 1357-1366, https://doi.org/10.1007/s13762-013-0204-5.

46. Rahmani-Sani, A.; Singh, P.; Raizada, P.; Claudio Lima, E.; Anastopoulos, I.; Giannakoudakis, D.A.; Sivamani, S.; Dontsova, T.A.; Hosseini-Bandegharaei, A. Use of Chicken Feather and Eggshell to Synthesize a Novel Magnetized Activated Carbon for Sorption of Heavy Metal Ions. Bioresour. Technol. 2020, 297, https://doi.org/10.1016/j.biortech.2019.122452.

47. Niju, S.; Begum, M.M.M.S.; Anantharaman, N. Modification of Egg Shell and Its Application in Biodiesel Production. J. Saudi Chem. Soc. 2014, 18, 702-706, https://doi.org/10.1016/j.jscs.2014.02.010.

48. Daraei, H.; Mittal, A.; Mittal, J.; Kamali, H. Optimization of Cr(VI) Removal onto Biosorbent Eggshell Membrane: Experimental \& Theoretical Approaches. Desalin. Water Treat. 2014, 52, 1307-1315, https://doi.org/10.1080/19443994.2013.787374.

49. (2-Fluorophenoxy)Acetic Acid | C8H7FO3 - PubChem Available online: https://pubchem.ncbi.nlm.nih.gov/compound/223073\#section=Synonyms (accessed on 22 February 2021).

50. Bumecaine $\mid$ C18H28N2O PubChem Available online: https://pubchem.ncbi.nlm.nih.gov/compound/65770\#section=Pharmacology-and-Biochemistry (accessed on 22 February 2021).

51. N-(2-Aminopropyl)Glycyl-L-Prolylalanine $\mid$ C13H24N4O4 | ChemSpider Available online: http://www.chemspider.com/Chemical-Structure.30855750.html (accessed on 22 February 2021).

52. 9064-67-9 Collagen (Cattle Skin) (9CI) Formula, NMR, Boiling Point, Density, Flash Point Available online: https://www.guidechem.com/dictionary/en/9064-67-9.html (accessed on 22 February 2021).

53. Lysozyme Chloride | C36H61N7O19 - PubChem Available online: https://pubchem.ncbi.nlm.nih.gov/compound/24839946 (accessed on 10 March 2021).

54. 1-Deoxy-5-Aza-D-Allopyran-Uronic Acid | C6H11NO6 - PubChem Available online: https://pubchem.ncbi.nlm.nih.gov/compound/91619589 (accessed on 10 March 2021).

55. Sucralose-6-Uronic Acid | C12H17Cl3O9 - PubChem Available online: https://pubchem.ncbi.nlm.nih.gov/compound/134687352 (accessed on 10 March 2021).

56. O-Sialic Acid | C11H19NO9 - PubChem Available online: https://pubchem.ncbi.nlm.nih.gov/compound/444885 (accessed on 10 March 2021).

57. Sialic Acids | C20H36N2O17 - PubChem Available online: https://pubchem.ncbi.nlm.nih.gov/compound/349960 (accessed on 10 March 2021).

58. Chondroitin Sulphate A | C14H23NO15S - PubChem Available online:
https://pubchem.ncbi.nlm.nih.gov/compound/4368136 (accessed on 10 March 2021). https://pubchem.ncbi.nlm.nih.gov/compound/4368136 (accessed on 10 March 2021).
Dermatan Sulfate | C14H21NO15S-2 - PubChem Available online:

https://pubchem.ncbi.nlm.nih.gov/compound/32756 (accessed on 10 March 2021).
60. Dermatan Hydrogen Sulphate | C18H31NO14S - PubChem Available online: https://pubchem.ncbi.nlm.nih.gov/compound/72682693 (accessed on 10 March 2021).

61. Hyaluronic Acid I C33H54N2O23 - PubChem Available online:

https://pubchem.ncbi.nlm.nih.gov/compound/24847767 (accessed on 10 March 2021).
62. Keratan C28H48N2O32S4 - PubChem Available
https://pubchem.ncbi.nlm.nih.gov/compound/446715 (accessed on 10 March 2021). 